\title{
Efficiency of Pollution Removal in Preliminary Settling Tanks of Household Wastewater Treatment Plants in the Roztocze National Park
}

\author{
Agnieszka Micek', Krzysztof Jóźwiakowski ${ }^{*}$, Michał Marzec' ${ }^{1}$ Agnieszka Listosz', \\ Arkadiusz Malik' \\ 1 Department of Environmental Engineering and Geodesy, University of Life Sciences in Lublin \\ Leszczyńskiego 7, 20-069 Lublin, Poland \\ * Corresponding author's e-mail: krzysztof.jozwiakowski@up.lublin.pl
}

\begin{abstract}
The paper presents an evaluation of the pollutant removal efficiencies of four primary settling tanks that were components of on-site domestic wastewater treatment plants located in the Roztocze National Park in Poland. We studied two four-chamber settling tanks which were elements of the technological lines of activated sludge treatment plants, and two three- chamber settling tanks which provided primary treatment in hybrid constructed wetlands. The tests were conducted in the years 2017-2019. During this period, wastewater samples for analysis were collected from the first chamber (raw wastewater) and the last chamber (primary settled wastewater) of each settling tank. We tested the following pollution parameters: total suspended solids (TSS), BOD, , COD, total nitrogen (TN), and total phosphorus (TP). The following mean pollutant removal efficiencies were obtained for the four-chamber settling tanks: TSS $-68.3 \%, \mathrm{BOD}_{5}-50.4 \%$, and COD $-49.5 \%$; the three-chamber settling tanks were much less efficient at reducing those pollution parameters: $50.9 \%, 17.0 \%$, and $2.3 \%$, respectively. Neither the three-chamber nor the four-chamber settling tanks ensured effective elimination of biogenic compounds. In most cases, the concentrations of TN and TP in primary settled wastewater were higher compared to raw sewage, which means that these elements were being released from sewage sludge during treatment. Despite this finding, the study shows that a primary settling tank should be used as a basic component of any domestic wastewater treatment plant, as it ensures a considerable reduction in TSS and organic matter.
\end{abstract}

Keywords: primary settling tank, pollutant removal efficiency, household wastewater treatment plants, domestic wastewater, Roztocze National Park

\section{INTRODUCTION}

According to the Polish Norm PN-EN 12566-3: 2016-10, a domestic wastewater treatment plant is a facility that can serve up to 50 people. The Water Law [2017] lays down the maximum capacity of this type of plant as $5 \mathrm{~m}^{3} \cdot \mathrm{d}^{-1}$. Every domestic wastewater treatment plant should consist of at least two stages of treatment: mechanical and biological. Wastewater is first treated mechanically in a primary settling tank, where sedimentation and flotation processes as well as anaerobic sediment stabilization take place [Dymaczewski et al.2011]. Then the effluent from the settling tank is treated biologically under aerobic conditions in sand filters, biological beds, activated sludge chambers, hybrid reactors (activated sludge + biological bed), or constructed wetlands [Jóźwiakowski 2012]. Treated wastewater can be discharged into the ground (through a soakaway well or a drainfield), water facilities, or surface waters [Jawecki et al. 2016].

According to Pawęski et al. [2011], a primary settling tank should be the basic element of every domestic wastewater treatment plant. The efficiency of a primary settling tank is crucial for the operation of the entire technological system, because it determines the composition of the 
wastewater directed into the biological stage, including ratios between pollutants.

The efficiency of a settling tank is influenced by numerous factors, the most important of which is its geometry, including surface area, length and depth [Razmi 2009]. According to OsmulskaMróz [1995], when one compares settling tanks with the same working volume, those which are shallower and have a larger surface area are more efficient, which is associated with a smaller rise in the wastewater level and a lower flow rate at the outflow from the tank. Other factors that influence the efficiency of settling tanks include surface hydraulic loading on the tank, wastewater retention time, type of settling tank, its shape, volume and division into chambers, type of wastewater, type of suspended solids and their content in wastewater, and temperature of the influent wastewater [Dymaczewski et al. 2011].

In accordance with PN-EN 12566-1:2004/ A1, a settling tank in a domestic wastewater treatment plant should have a working volume of at least $2.0 \mathrm{~m}^{3}$. According to other recommendations formulated in the literature, the active capacity of a settling tank in domestic wastewater treatment plants should not be less than $3 \mathrm{~m}^{3}$ [Heidrich 1998; Osmulska-Mróz 1995; Pawęska et al. 2011]. Two types of primary settling tanks are used for mechanical treatment of sewage: settling tanks with a very short wastewater retention time (several hours) and settling tanks with a long wastewater retention time (several to several days), so-called settling tanks. Settling tanks with a short retention time are used in large, centralized treatment facilities to treat sewage mechanically before it enters the biological treatment stage. On the other hand, in settling tanks used in domestic wastewater treatment plants, wastewater is retained for longer than one day [Makowska et al. 2018].

Some studies show that the number of chambers and the shape of the baffle (partition) do not significantly affect the removal of suspended solids in the settling tank [Roth and Lowe 2007; Seabloom et al. 2004; Jowett 2007], and the largest amount of sludge is always retained in the first chamber, in the inflow zone of the tank [Pawęska et al. 2011]. Conversely, studies by Razmi et al. [2009] and Tamayol et al. [2010] indicate that the rates of pollutant reduction in a settling tank do depend on the number of compartments and the configuration of partitions. Compartmentalization affects the distribution of wastewater flow velocity and the model of wastewater flow. It also helps eliminate the adverse effect of large fluctuations in flow intensity, preventing mixing and turbulent flow of sewage and stopping sludge particles from being carried to the top. Moreover, compartmentalization of a settling tank, in conjunction with increasing its horizontal surface, exclude the risk of high concentrations of suspended solids sedimenting at the outflow from the settling tank at maximum hourly loading rates [Shahrokhi et al. 2013].

Because sedimentation and flotation of pollutants play a dominant role in the mechanical treatment of wastewater, primary settling tanks are designed to mainly remove easily settling suspended solids. The rate of removal of such particles in settling tanks is usually $60-70 \%$. Because domestic wastewater characteristically contains large quantities of organic suspended solids, settling tanks also substantially reduce the concentrations of $\mathrm{BOD}_{5}$ and $\mathrm{COD}$, by as much as $25-40 \%$ [Dymaczewski et al. 2011]. When it comes to the removal of biogenic pollutants, their efficiency is relatively low [Paluch et al. 2006; Philippi et al. 1999].

The purpose of this study was to assess the operation of four settling tanks which provided primary treatment in on-site domestic wastewater treatment plants in the Roztocze National Park in Poland. Four tanks were investigated: two four-chamber settling tanks that were part of the technological lines of activated sludge treatment plants, and two three-chamber settling tanks used in hybrid constructed wetlands.

\section{Facilities}

The Roztocze National Park (RNP), in which the investigated facilities had been built, is located in the Lublin Province, in south-eastern Poland. Together with the buffer zone, it spans the area of five communes of Zamość County (Zwierzyniec, Szczebrzeszyn, Adamów, Zamość, and Krasnobród). In administrative terms, the largest part of the park is situated in the commune of Zwierzyniec. In physical geographical terms, the park is located in the area of Central Roztocze [Świeca et al. 2016].

The RPN covers a surface area of 8.5 thousand ha. It is mostly woodland (95.5\%), with 1029 ha $(12.1 \%)$ of woods strictly protected by law. The diverse habitat conditions of this area promote the occurrence of many interesting forest communities 
with rich vegetation, including numerous species of trees and shrubs [Buraczyński 2013].

The RPN has a dispersed development pattern, which makes difficult the expansion of utility infrastructure. This applies in particular to the possibility of providing water supply and sanitation services to a larger number of people and constructing new wastewater treatment plants. The choice of an appropriate wastewater treatment system in protected areas such as the RPN should be made in accordance with the principles of sustainable development, taking into account a variety of criteria [Jóźwiakowski et al. 2015].

A survey conducted in 2016 shows that the communes encompassed by the RPN and its buffer zone have a relatively high water supply coverage of $80 \%$. [Jóźwiakowski et al. 2017]. The sanitation coverage level is much lower at $39.8 \%$. According to the survey, there are 14209 cesspools in the communes located in the RPN and 64 domestic wastewater treatment plants.

Four primary settling tanks were selected for the study, all of which were components of the technological lines of domestic wastewater treatment plants. The treatment plants serviced forest hamlets situated in the RPN and had been built in 2014-2015. Two of the settling tanks (1 and 2) were located in Zwierzyniec and Florianka and were components of hybrid constructed wetlands (Fig. 1). They were concrete tanks, divided into four compartments connected by overflow pipes. The overflow pipes were located below the wastewater level and were fitted with tees to prevent the passage of impurities separated by flotation. Because the biological stage included a vertical subsurface flow bed which had to be fed with mechanically treated wastewater under pressure, the fourth chamber in settling tanks No. 1 and 2 served as a pumping station. Primary settling tanks No. 3 and 4 were part of two domestic wastewater treatment plants with activated sludge located in Obrocza and Rybakówka, respectively (Fig. 1) They were also made from concrete and divided into four chambers with sunken overflows fitted with tees. In the case of these tanks, all four chambers were used to treat wastewater mechanically, because the effluent from them was transported into the biological treatment stage by gravity. The technological parameters of the analyzed primary settling tanks are given in Table 1, and schematics of the tanks are shown in Figure 2.

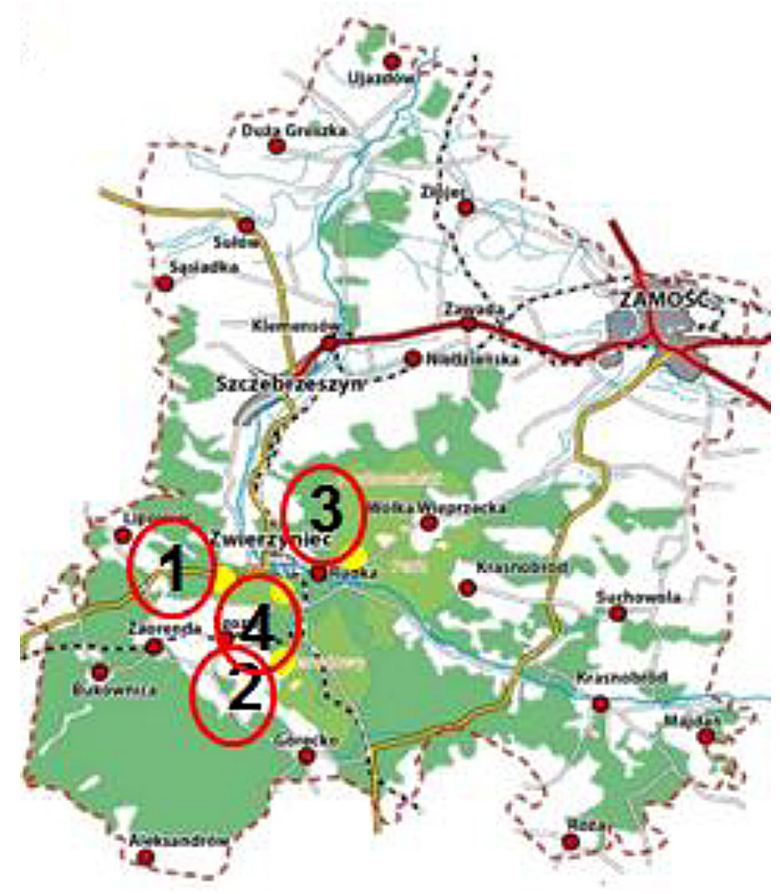

Fig. 1. Geographical location of investigated primary settling tanks in the Roztocze National Park (1 - Zwierzyniec, 2 - Florianka, 3 - Obrocz, 4 - Rybakówka)

\section{METHOD}

The tests of the pollutant removal efficiency of the primary settling tanks were carried out in the years 2017-2019. During this period, samples of raw wastewater and primary settled wastewater were taken from the first and last chambers of each tank, respectively. Samples were tested in the Water and Wastewater Testing Laboratory of Department of Environmental Engineering and Geodesy, University of Life Sciences in Lublin, Poland. During the study period, 20 test runs were completed, in which a total of 160 wastewater samples were collected and tested. Sampling was done in accordance with the Polish standard PN$74 / \mathrm{C}-04620 / 00$. The analyses were carried out using the recommended methods [Regulation of the Minister of Environment 2014], and covered the following pollution parameters:

- TSS - direct gravimetry using filtration through paper filters;

- $\mathrm{BOD}_{5}$ - dilution and seeding procedures with an addition of allylthiourea based on dissolved oxygen concentration measured immediately after sampling and after 5 days of incubation (oxygen content was determined using a Thermo Scientific ORION Star A329 multi-parameter meter); 
Table 1. Technological parameters of the investigated primary settling tanks

\begin{tabular}{|c|c|c|c|c|}
\hline \multirow{2}{*}{ Technological parameters } & \multicolumn{4}{|c|}{ Primary settling tank } \\
\hline & No. 1 & No. 2 & No. 3 & No. 4 \\
\hline Year of construction & 2014 & 2015 & 2014 & 2014 \\
\hline Number of users & 4 & 10 & 6 & 10 \\
\hline Number of chambers & 3 & 3 & 4 & 4 \\
\hline Tank volume $\left[\mathrm{m}^{3}\right]$ & 4.9 & 4.9 & 5.7 & 5.7 \\
\hline Chamber volume $\left[\mathrm{m}^{3}\right]$ & $\begin{array}{r}I-2.0 \\
I I-1.3 \\
I I I-1.6\end{array}$ & $\begin{array}{l}I-2.0 \\
I I-1.3 \\
I I I-1.6\end{array}$ & $\begin{array}{l}\mathrm{I}-2.0 \\
\mathrm{II}-1.3 \\
\mathrm{III}-1.6 \\
\mathrm{IV}-0.6\end{array}$ & $\begin{array}{l}I-2.0 \\
I I-1.3 \\
I I I-1.6 \\
I V-0.6\end{array}$ \\
\hline $\begin{array}{l}\text { Average daily wastewater } \\
\text { load } Q\left[\mathrm{~m}^{3} \cdot \mathrm{d}^{-1}\right]\end{array}$ & 0.4 & 1.0 & 1.0 & 1.6 \\
\hline
\end{tabular}
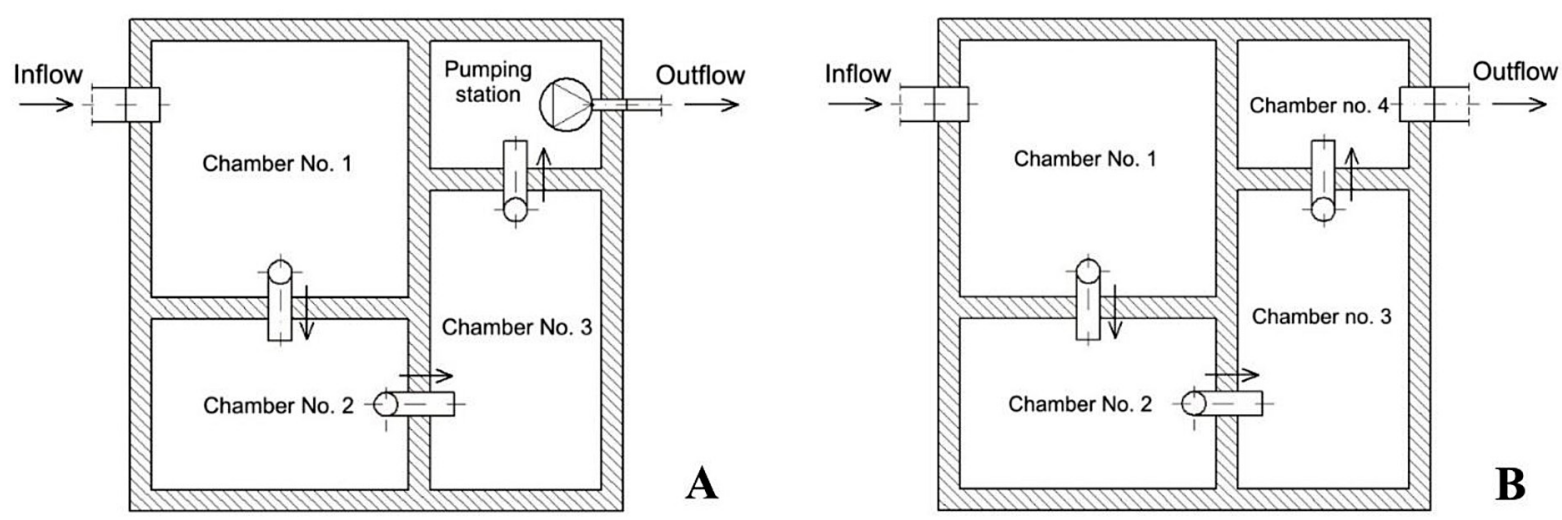

Fig. 2. Schematics of primary settling tanks: A - a three-chamber tank, B - a four-chamber tank

- $\mathrm{COD}_{\mathrm{cr}}$ - the bichromate method with prior oxidation of the test sample in a thermoreactor at $148^{\circ} \mathrm{C}$ (COD determinations were made using a Macherey-Nagel Nanocolor@ VIS spectrophotometer);

- $\mathrm{TN}$ - determinations were made using a Macherey-Nagel Nanocolor @ VIS spectrophotometer after oxidation of the test sample in a thermoreactor at $120{ }^{\circ} \mathrm{C}$;

- ammonium nitrogen, nitrate nitrogen and nitrite nitrogen - determinations were made using a Macherey-Nagel Nanocolor@ VIS spectrophotometer;

- TP - determinations were made using a Macherey-Nagel Nanocolor @ VIS spectrophotometer after oxidation of the test sample in a thermoreactor at $120^{\circ} \mathrm{C}$;

- $\mathrm{pH}$ and dissolved oxygen concentration were determined using a Thermo Scientific ORION Star A329 multi-parameter meter.

The results of the tests were used to determine the minimum, maximum, mean, and median values, coefficient of variation, and standard deviation for each pollution parameter. Data variation was assessed based on Mucha [1994] classification of variation (Table 2)

The pollutant removal efficiencies of the analyzed primary settling tanks were calculated using Formula 1:

$$
\eta=100\left(1-\frac{C_{\text {out }}}{C_{\text {in }}}\right) \%
$$

where: $C_{\text {out }}-$ concentration of pollutants in wastewater flowing out of the settling tank $\left[\mathrm{mg} \cdot \mathrm{dm}^{-3}\right]$,

$C_{\text {in }}-$ concentration of pollutants in wastewater flowing into the settling tank $\left[\mathrm{mg} \cdot \mathrm{dm}^{-3}\right]$.

Table 2. Classification of variation Mucha 1994]

\begin{tabular}{|c|c|c|}
\hline Variation group & Variation & V \\
\hline I & low & $0-20$ \\
\hline II & moderate & $20-40$ \\
\hline III & high & $40-100$ \\
\hline IV & very high & $100-150$ \\
\hline V & extremely high & $>150$ \\
\hline
\end{tabular}


We also determined ratios between mean values of the pollution parameters and assessed the susceptibility of the mechanically treated wastewater to biochemical degradation and removal of biogenic compounds in the biological treatment stage. The assessment was based on ratio recommendations by Heidrich et al. [2008] and Młyńska et al. [2017].

\section{RESULTS AND DISCUSSION}

\section{Composition of raw wastewater}

Domestic wastewater is wastewater from homes, collective housing, and public buildings originating from the use of toilet and other household facilities, and wastewater of a similar composition originating from these buildings [Water Law 2017]. Wastewater from households and public buildings contains organic and inorganic substances, such as human and animal excreta, food waste, detergents, etc. [Heidrich et al. 2008].

Dissolved oxygen. Fresh sewage can contain up to several $\mathrm{mg} \mathrm{O} \cdot \mathrm{dm}^{-3}$. In stale sewage, which has been stored for a long time in a settling tank, the concentration of oxygen falls below $0.5 \mathrm{mg} \mathrm{O}_{2} \cdot \mathrm{dm}^{-3}$ [Heidrich et al. 2008]. In our study, wastewater flowing into the settling tanks had low concentrations of dissolved oxygen. They ranged from $0.70 \mathrm{mg} \mathrm{O} \cdot \mathrm{dm}^{-3}$ in tank No. 2 to $1.10 \mathrm{mg} \mathrm{O}_{2} \cdot \mathrm{dm}^{-3}$ in tank No. 4 , which indicates that the sewage was most likely fresh sewage.

pH. According to literature data, biological wastewater treatment processes work properly at $\mathrm{pH}$ in the range of 6.6-8.0 [Dymaczewski et al. 2011; Heidrich et al. 2008]. In the facilities we studied, raw sewage had $\mathrm{pH}$ values in this range: from 6.57 to 8.29 (Tables 3-6), which means it was weakly acidic or weakly basic.

BOD $_{5}$. The mean content of organic pollutants (expressed as $\mathrm{BOD}_{5}$ ) in the wastewater flowing into the analyzed primary settling tanks ranged from 108 to $381.2 \mathrm{mgO}_{2} \cdot \mathrm{dm}^{-3}$, with the highest value recorded for tank No. 1, and the lowest for tank No. 3 (Tables 3-6). The values we obtained were similar to those reported by other authors. Błażejewski [2003] recorded a mean $\mathrm{BOD}_{5}$ value of $300 \mathrm{mgO}_{2} \cdot \mathrm{dm}^{-3}$ in raw domestic wastewater. In a study by Gizińska-Górna et al. [2015] the value of this parameter in the influent into two settling tanks ranged from 321.5 to $692.2 \mathrm{mgO}_{2} \cdot \mathrm{dm}^{-3}$. In turn, Chmielowski and Bugajski [2008] obtained $\mathrm{BOD}_{5}$ values in the range of $251.9-437.7 \mathrm{mgO}_{2} \cdot \mathrm{dm}^{-3}$ in raw sewage flowing into the settling tank of a domestic wastewater treatment plant.

COD. The mean $\mathrm{COD}_{\mathrm{Cr}}$ value in the influent into the analyzed settling tanks ranged from 343 to $921 \mathrm{mgO}_{2} \cdot \mathrm{dm}^{-3}$. Sadecka and PłuciennikKoropczuk [2011] recorded a mean COD value of $480 \mathrm{mgO}_{2} \cdot \mathrm{dm}^{-3}$ in raw wastewater from the "Eaccza" wastewater treatment plant in Zielona Góra, Polnd. As in the case of $\mathrm{BOD}_{5}$, the highest COD value was found in samples of wastewater from tank No. 1, the lowest - in wastewater from tank No. 3. It is worth mentioning here that primary settling tank No. 1 collected wastewater from a residential building, which may explain the high content of organic pollutants. Sewage discharged from houses contains pollutants originating from various household activities, such as washing dishes and cooking, which can generate large amounts of organic waste. In turn, settling

Table 3. Composition of raw and primary settled wastewater in primary settling tank No. 1

\begin{tabular}{|c|c|c|c|c|c|c|c|c|c|c|c|c|c|c|c|}
\hline \multirow{3}{*}{\multicolumn{2}{|c|}{ Parameters }} & \multicolumn{14}{|c|}{ Tank No. 1} \\
\hline & & \multicolumn{2}{|c|}{ mean } & \multicolumn{2}{|c|}{ median } & \multicolumn{2}{|c|}{$\min$} & \multicolumn{2}{|c|}{$\max$} & \multicolumn{2}{|c|}{$\begin{array}{l}\text { standard } \\
\text { deviation }\end{array}$} & \multicolumn{2}{|c|}{$\begin{array}{l}\text { coefficient of } \\
\text { variability }\end{array}$} & \multicolumn{2}{|c|}{$\begin{array}{l}\text { variability } \\
\text { group }\end{array}$} \\
\hline & & in & out & in & out & in & out & in & out & in & out & in & out & in & out \\
\hline $\mathrm{pH}$ & - & 7.18 & 7.31 & 7.03 & 7.32 & 6.76 & 7.00 & 7.95 & 7.66 & 0.36 & 0.19 & 0.05 & 0.03 & I & I \\
\hline Dissolved oxygen & $\mathrm{mg} \mathrm{O}_{2} \cdot \mathrm{dm}^{-3}$ & 0.84 & 0.50 & 0.81 & 0.33 & 0.09 & 0.02 & 2.41 & 1.64 & 0.64 & 0.51 & 0.76 & 1.03 & III & IV \\
\hline $\begin{array}{l}\text { Total suspended } \\
\text { solids }\end{array}$ & $\mathrm{mg} \cdot \mathrm{dm}^{-3}$ & 192.2 & 111.7 & 169.7 & 103 & 116 & 56.0 & 500 & 242.1 & 92.33 & 49.21 & 0.48 & 0.44 & III & III \\
\hline $\mathrm{BOD}_{5}$ & $\mathrm{mg} \mathrm{O}_{2} \cdot \mathrm{dm}^{-3}$ & 381.2 & 281.0 & 358.0 & 285 & 282 & 193.5 & 647 & 345 & 85.01 & 38.36 & 0.22 & 0.14 & II & 1 \\
\hline $\mathrm{COD}_{\mathrm{Cr}}$ & $\mathrm{mg} \mathrm{O}_{2} \cdot \mathrm{dm}^{-3}$ & 921 & 810 & 907 & 789 & 94.1 & 575 & 1890 & 1220 & 330.9 & 147.1 & 0.36 & 0.18 & II & 1 \\
\hline Ammonium nitrogen & $\mathrm{mg} \mathrm{N}-\mathrm{NH}_{4} \cdot \mathrm{dm}^{-3}$ & 109.4 & 111.3 & 106.0 & 113.0 & 65.0 & 79.0 & 148.0 & 139.0 & 20.1 & 18.1 & 0.18 & 0.16 & I & I \\
\hline Nitrate nitrogen & $\mathrm{mg} \mathrm{N}-\mathrm{NO}_{3} \cdot \mathrm{dm}^{-3}$ & 1.13 & 1.12 & 0.80 & 1.00 & 0.09 & 0.10 & 3.26 & 2.70 & 0.90 & 0.68 & 0.80 & 0.61 & III & III \\
\hline Nitrite nitrogen & $\mathrm{mg} \mathrm{N}-\mathrm{NO}_{2} \cdot \mathrm{dm}^{-3}$ & 0.23 & 0.22 & 0.22 & 0.18 & 0.01 & 0.01 & 0.39 & 0.41 & 0.09 & 0.11 & 0.40 & 0.50 & III & III \\
\hline Total nitrogen & $\mathrm{mg} \mathrm{TN} \cdot \mathrm{dm}^{-3}$ & 128.6 & 146.5 & 123.0 & 148.0 & 84.5 & 82.9 & 175.0 & 209.0 & 24.8 & 30.9 & 0.19 & 0.21 & I & II \\
\hline Total phosphorus & $\mathrm{mg} \mathrm{TP} \cdot \mathrm{dm}^{-3}$ & 19.2 & 26.2 & 18.1 & 20.8 & 12.5 & 14.2 & 36.2 & 71.8 & 6.1 & 14.2 & 0.3 & 0.5 & II & III \\
\hline
\end{tabular}


Table 4. Composition of raw and primary settled wastewater in primary settling tank No. 2

\begin{tabular}{|c|c|c|c|c|c|c|c|c|c|c|c|c|c|c|c|}
\hline \multirow{3}{*}{\multicolumn{2}{|c|}{ Parameters }} & \multicolumn{14}{|c|}{ Tank No. 2} \\
\hline & & \multicolumn{2}{|c|}{ mean } & \multicolumn{2}{|c|}{ median } & \multicolumn{2}{|c|}{$\min$} & \multicolumn{2}{|c|}{$\max$} & \multicolumn{2}{|c|}{$\begin{array}{l}\text { standard } \\
\text { deviation }\end{array}$} & \multicolumn{2}{|c|}{$\begin{array}{l}\text { coefficient } \\
\text { of } \\
\text { variability }\end{array}$} & \multicolumn{2}{|c|}{$\begin{array}{c}\text { variability } \\
\text { group }\end{array}$} \\
\hline & & in & out & in & out & in & out & in & out & in & out & in & out & in & out \\
\hline $\mathrm{pH}$ & - & 7.17 & 7.19 & 7.12 & 7.20 & 6.96 & 6.88 & 7.47 & 7.47 & 0.13 & 0.15 & 0.02 & 0.02 & I & I \\
\hline Dissolved oxygen & $\mathrm{mg} \mathrm{O}_{2} \cdot \mathrm{dm}^{-3}$ & 0.70 & 0.67 & 0.62 & 0.49 & 0.15 & 0.02 & 1.68 & 2.33 & 0.48 & 0.67 & 0.68 & 1.01 & III & IV \\
\hline $\begin{array}{l}\text { Total suspended } \\
\text { solids }\end{array}$ & $\mathrm{mg} \cdot \mathrm{dm}^{-3}$ & 165 & 66.4 & 92.8 & 58.7 & 28.9 & 25.0 & 776 & 104 & 187 & 23.4 & 1.1 & 0.3 & IV & II \\
\hline $\mathrm{BOD}_{5}$ & $\mathrm{mg} \mathrm{O}_{2} \cdot \mathrm{dm}^{-3}$ & 142 & 131 & 126 & 122 & 50.0 & 22.5 & 263 & 295 & 61.7 & 76.3 & 0.4 & 0.6 & III & III \\
\hline $\mathrm{COD}_{\mathrm{Cr}}$ & $\mathrm{mg} \mathrm{O}_{2} \cdot \mathrm{dm}^{-3}$ & 389 & 418 & 381 & 437 & 218 & 188 & 630 & 700 & 122 & 166 & 0.3 & 0.4 & II & III \\
\hline Ammonium nitrogen & $\mathrm{mg} \mathrm{N}-\mathrm{NH}_{4} \cdot \mathrm{dm}^{-3}$ & 79.9 & 77.7 & 82.0 & 78.0 & 60.0 & 59.0 & 99.0 & 95.0 & 10.2 & 9.4 & 0.1 & 0.1 & 1 & 1 \\
\hline Nitrate nitrogen & $\mathrm{mg} \mathrm{N}-\mathrm{NO}_{3} \cdot \mathrm{dm}^{-3}$ & 0.66 & 0.70 & 0.50 & 0.80 & 0.09 & 0.03 & 1.60 & 1.80 & 0.50 & 0.54 & 0.76 & 0.78 & III & III \\
\hline Nitrite nitrogen & $\mathrm{mg} \mathrm{N}-\mathrm{NO}_{2} \cdot \mathrm{dm}^{-3}$ & 0.11 & 0.11 & 0.11 & 0.11 & 0.01 & 0.01 & 0.20 & 0.27 & 0.05 & 0.06 & 0.43 & 0.51 & III & III \\
\hline Total nitrogen & $\mathrm{mg} \mathrm{TN} \cdot \mathrm{dm}^{-3}$ & 97.3 & 100.5 & 97.0 & 98.0 & 61.7 & 62.0 & 129.0 & 146.0 & 16.5 & 21.0 & 0.1 & 0.2 & 1 & II \\
\hline Total phosphorus & $\mathrm{mg} \mathrm{TP} \cdot \mathrm{dm}^{-3}$ & 16.0 & 20.1 & 15.7 & 19.2 & 9.3 & 10.3 & 35.0 & 48.3 & 7.1 & 10.1 & 0.4 & 0.5 & III & III \\
\hline
\end{tabular}

tank No. 3 was fed with wastewater from an administration building, which may explain the lower concentration of organic pollutants.

Total suspended solids. Literature reports show that the concentrations of TSS in raw rural wastewater can be variable and very high. In a study by Chmielowski and Ślizowski [2009], influent into a settling tank contained $347 \mathrm{mg} \cdot \mathrm{dm}^{-3}$ of TSS. Miernik and Młyński [2014] recorded TSS concentrations in the range from 143 to $576 \mathrm{mg} \cdot \mathrm{dm}^{-3}$ in raw sewage flowing into a treatment plant in Krzeszowice. In this present study, the mean concentrations of TSS in raw domestic sewage ranged from 71.2 to $192.2 \mathrm{mg} \cdot \mathrm{dm}^{-3}$ (Tables 3-6).

\section{Total nitrogen and nitrogen compounds.}

The nitrogen compounds found in domestic wastewater are mainly associated with organic waste and usually contain nitrogen in different oxidation states. Knowledge of the concentrations of these compounds has an impact on the course of its treatment [Heidrich et al. 2008]. According to the Regulation of the Polish Minister of Marine Economy and Inland Navigation [2019], the sum of all forms of nitrogen (ammonium, organic, nitrate, and nitrite $\mathrm{N}$ ) is defined as total nitrogen. In this study, TN concentrations in raw sewage flowing into the facilities in the area of the RNP ranged from 97.3 to $179 \mathrm{mg} \cdot \mathrm{dm}^{-3}$ (Tables 3-6). The highest TN concentrations were recorded in the wastewater flowing into settling tank No. 3 (Table 5), which may have been an effect of a high content of fecal matter discharged into that tank from the administration building. In tanks No. 1 and 4, the influent contained 128.6 and $129 \mathrm{mg} \cdot \mathrm{dm}^{-3}$ TN, respectively. Masłoń and Tomaszek [2013] recorded much lower levels of TN in raw sewage $\left(73.79 \mathrm{mg} \cdot \mathrm{dm}^{-3}\right)$. In a study by Maciołek et al. [2016] TN concentrations in raw sewage ranged

Table 5. Composition of raw and primary settled wastewater in primary settling tank No. 3

\begin{tabular}{|c|c|c|c|c|c|c|c|c|c|c|c|c|c|c|c|}
\hline \multirow{3}{*}{\multicolumn{2}{|c|}{ Parameters }} & \multicolumn{14}{|c|}{ Tank No. 3} \\
\hline & & \multicolumn{2}{|c|}{ mean } & \multicolumn{2}{|c|}{ median } & \multicolumn{2}{|c|}{$\min$} & \multicolumn{2}{|c|}{$\max$} & \multicolumn{2}{|c|}{$\begin{array}{l}\text { standard } \\
\text { deviation }\end{array}$} & \multicolumn{2}{|c|}{$\begin{array}{l}\text { coefficient of } \\
\text { variability }\end{array}$} & \multicolumn{2}{|c|}{$\begin{array}{l}\text { variability } \\
\text { group }\end{array}$} \\
\hline & & in & out & in & out & in & out & in & out & in & out & in & out & in & out \\
\hline $\mathrm{pH}$ & - & 7.78 & 8.07 & 7.83 & 8.08 & 7.29 & 7.90 & 8.29 & 8.22 & 0.31 & 0.10 & 0.04 & 0.01 & 1 & 1 \\
\hline Dissolved oxygen & $\mathrm{mg} \mathrm{O}_{2} \cdot \mathrm{dm}^{-3}$ & 1.05 & 1.62 & 0.87 & 1.14 & 0.07 & 0.23 & 3.77 & 7.02 & 0.95 & 1.63 & 0.91 & 1.00 & III & IV \\
\hline $\begin{array}{l}\text { Total suspended } \\
\text { solids }\end{array}$ & $\mathrm{mg} \cdot \mathrm{dm}^{-3}$ & 71.2 & 28.7 & 51.4 & 21.3 & 18.4 & 5.3 & 240 & 69.0 & 59.8 & 20.9 & 0.8 & 0.7 & III & III \\
\hline $\mathrm{BOD}_{5}$ & $\mathrm{mg} \mathrm{O}_{2} \cdot \mathrm{dm}^{-3}$ & 108 & 53.02 & 118 & 62.0 & 25.0 & 12.3 & 152 & 80.0 & 44.1 & 22.1 & 0.4 & 0.4 & III & III \\
\hline $\mathrm{COD}_{\mathrm{Cr}}$ & $\mathrm{mg} \mathrm{O}_{2} \cdot \mathrm{dm}^{-3}$ & 343 & 180 & 339 & 180 & 131 & 111 & 479 & 236 & 102 & 34.3 & 0.30 & 0.19 & II & I \\
\hline Ammonium nitrogen & $\mathrm{mg} \mathrm{N}-\mathrm{NH}_{4} \cdot \mathrm{dm}^{-3}$ & 153.2 & 136.0 & 151.0 & 133.0 & 117.0 & 111.0 & 193.0 & 172.0 & 23.3 & 17.2 & 0.15 & 0.13 & 1 & I \\
\hline Nitrate nitrogen & $\mathrm{mg} \mathrm{N}-\mathrm{NO}_{3} \cdot \mathrm{dm}^{-3}$ & 0.88 & 1.97 & 0.80 & 1.25 & 0.00 & 0.09 & 1.70 & 5.70 & 0.50 & 1.89 & 0.57 & 0.96 & III & III \\
\hline Nitrite nitrogen & $\mathrm{mg} \mathrm{N}-\mathrm{NO}_{2} \cdot \mathrm{dm}^{-3}$ & 0.08 & 0.31 & 0.08 & 0.06 & 0.04 & 0.03 & 0.17 & 1.17 & 0.03 & 0.43 & 0.38 & 1.37 & II & IV \\
\hline Total nitrogen & $\mathrm{mg} \mathrm{TN} \cdot \mathrm{dm}^{-3}$ & 179 & 160 & 187 & 163 & 124 & 121 & 219 & 207 & 34.2 & 24.4 & 0.19 & 0.15 & 1 & I \\
\hline Total phosphorus & $\mathrm{mg} \mathrm{TP} \cdot \mathrm{dm}^{-3}$ & 18.5 & 12.0 & 15.3 & 11.1 & 10.0 & 8.2 & 44.8 & 17.2 & 9.6 & 3.0 & 0.6 & 0.2 & III & II \\
\hline
\end{tabular}


Table 6. Composition of raw and primary settled wastewater in primary settling tank No. 4

\begin{tabular}{|c|c|c|c|c|c|c|c|c|c|c|c|c|c|c|c|}
\hline \multirow{3}{*}{\multicolumn{2}{|c|}{ Parameters }} & \multicolumn{14}{|c|}{ Tank No. 4} \\
\hline & & \multicolumn{2}{|c|}{ mean } & \multicolumn{2}{|c|}{ median } & \multicolumn{2}{|c|}{$\min$} & \multicolumn{2}{|c|}{$\max$} & \multicolumn{2}{|c|}{$\begin{array}{l}\text { standard } \\
\text { deviation }\end{array}$} & \multicolumn{2}{|c|}{$\begin{array}{c}\text { coefficient } \\
\text { of } \\
\text { variability }\end{array}$} & \multicolumn{2}{|c|}{$\begin{array}{l}\text { variability } \\
\text { group }\end{array}$} \\
\hline & & in & out & in & out & in & out & in & out & in & out & in & out & in & out \\
\hline $\mathrm{pH}$ & - & 7.04 & 7.79 & 6.9 & 7.46 & 6.57 & 7.04 & 7.86 & 11.9 & 0.43 & 1.17 & 0.06 & 0.15 & I & I \\
\hline $\begin{array}{l}\text { Dissolved } \\
\text { oxygen }\end{array}$ & $\mathrm{mg} \mathrm{O}_{2} \cdot \mathrm{dm}^{-3}$ & 1.10 & 1.29 & 0.95 & 0.94 & 0.25 & 0.21 & 3.34 & 3.75 & 0.72 & 1.09 & 0.65 & 0.84 & III & III \\
\hline $\begin{array}{l}\text { Total suspended } \\
\text { solids }\end{array}$ & $\mathrm{mg} \cdot \mathrm{dm}^{-3}$ & 149 & 34.5 & 84.9 & 32.7 & 21.8 & 3.8 & 513 & 116 & 144 & 31.0 & 1.0 & 0.9 & III & III \\
\hline $\mathrm{BOD}_{5}$ & $\mathrm{mg} \mathrm{O}_{2} \cdot \mathrm{dm}^{-3}$ & 171 & 85.6 & 189 & 89 & 21 & 16 & 273 & 250 & 75 & 58.2 & 0.4 & 0.7 & III & III \\
\hline $\mathrm{COD}_{\mathrm{Cr}}$ & $\mathrm{mg} \mathrm{O}_{2} \cdot \mathrm{dm}^{-3}$ & 516 & 251 & 526 & 237 & 172 & 109 & 720 & 400 & 153 & 88 & 0.3 & 0.4 & II & II \\
\hline $\begin{array}{l}\text { Ammonium } \\
\text { nitrogen }\end{array}$ & $\mathrm{mg} \mathrm{N}-\mathrm{NH}_{4} \cdot \mathrm{dm}^{-3}$ & 109 & 97.6 & 113 & 103 & 43.0 & 58 & 164 & 134 & 31.0 & 19.7 & 0.29 & 0.20 & II & I \\
\hline Nitrate nitrogen & $\mathrm{mg} \mathrm{N}-\mathrm{NO}_{3} \cdot \mathrm{dm}^{-3}$ & 0.76 & 0.62 & 0.65 & 0.6 & 0.1 & 0.18 & 1.6 & 1.2 & 0.52 & 0.32 & 0.68 & 0.52 & III & III \\
\hline Nitrite nitrogen & $\mathrm{mg} \mathrm{N}-\mathrm{NO}_{2} \cdot \mathrm{dm}^{-3}$ & 0.11 & 0.14 & 0.1 & 0.07 & 0.06 & 0.05 & 0.22 & 0.76 & 0.04 & 0.20 & 0.37 & 1.39 & II & I \\
\hline Total nitrogen & $\mathrm{mg} \mathrm{TN} \cdot \mathrm{dm}^{-3}$ & 129 & 117 & 125 & 114 & 54.0 & 60.0 & 211 & 182 & 42.7 & 25.1 & 0.3 & 0.2 & II & II \\
\hline Total phosphorus & $\mathrm{mg}$ TP. $\mathrm{dm}^{-3}$ & 16.7 & 17.3 & 15.8 & 15.3 & 4.9 & 11.4 & 33.9 & 30.9 & 7.2 & 5.7 & 0.4 & 0.3 & III & II \\
\hline
\end{tabular}

from 80 to $110 \mathrm{mg} \cdot \mathrm{dm}^{-3}$. In all these studies, the dominant form of nitrogen in raw sewage was ammonium nitrogen, which constituted on average $80-85 \%$ of TN (Table $3-6$ ).

Other forms of nitrogen were present in very small amounts in raw sewage. The concentrations of $\mathrm{N}-\mathrm{NO}_{3}$ ranged from $0.66 \mathrm{mg} \cdot \mathrm{dm}^{-3}$ for tank No. 2 to $1.13 \mathrm{mg} \cdot \mathrm{dm}^{-3}$ for tank No.1. The lowest nitrite concentrations were recorded for tank No. 3 .

Total phosphorus. Phosphorus occurs in wastewater in dissolved form and in sediment in the form of orthophosphates, polyphosphates, and organic phosphorus [Heidrich et al. 2008]. Phosphorus compounds are not toxic, but high concentrations of phosphorus in aquatic ecosystems cause eutrophication. The phosphorus content in raw sewage is variable and depends on the amounts of detergents, cleaning products, and other products with different phosphorus contents used in a household [Wiejak 2013]. In this study, the mean TP concentrations in raw sewage flowing into the settling tanks ranged from 16.0 to $19.2 \mathrm{mg} \cdot \mathrm{dm}^{-3}$. Chmielowski and Ślizowski [2009], who studied a wastewater treatment plant in Tarnów, Poland, recorded TP concentrations of $6-10 \mathrm{mg} \cdot \mathrm{dm}^{-3}$ in urban wastewater flowing into the plant. A higher TP concentration of $22.05 \mathrm{mg} \cdot \mathrm{dm}^{-3}$ was observed in a study by Gizińska-Górna et al. [2015].

\section{Composition of primary settled wastewater and treatment efficiency}

BOD $_{5}$. The mean $\mathrm{BOD}_{5}$ value in the effluent from the investigated settling tanks ranged from
$53.02 \mathrm{mgO}_{2} \cdot \mathrm{dm}^{-3}$ for tank No. 3 to $281 \mathrm{mgO} \cdot \mathrm{dm}^{-3}$ for tank No. 1. The test results show clear differences between the 3- and the four-chamber settling tanks in the efficiency of removing organic pollutants. The mean $\mathrm{BOD}_{5}$ reduction efficiency of the three-chamber settling tanks was $26.3 \%$ and $7.7 \%$. The four-chamber settling tanks reduced mean $\mathrm{BOD}_{5}$ by 50.9 and $49.9 \%$. Fig. 3 )

Settling tanks No. 1 and 2 were fed with typical domestic wastewater discharged from residential buildings; the specific character of the influent may have determined the efficiency of removal of pollutants. Accumulation of a larger layer of sediments in the settling tanks and their initial decomposition may have been the cause of the appearance of larger amounts of dissolved organic compounds at the outflow. Results comparable to those obtained for tanks No. 3 and 4 were obtained by Gizińska-Górna et al. [2015] for a 2-chamber settling tank. In their study, a fourchamber settling tank had a $30 \% \mathrm{BOD}_{5}$ reduction efficiency.

COD. The mean $\mathrm{COD}_{\mathrm{Cr}}$ value in the effluent from the tested settling tanks ranged from $180 \mathrm{mg}$ $\mathrm{O}_{2} \cdot \mathrm{dm}^{-3}$ for tank No. 3 to $810 \mathrm{mg} \mathrm{O}_{2} \cdot \mathrm{dm}^{-3}$ for tank No. 1. In the three-chamber settling tank No. 2, the COD level increased during mechanical treatment by $7.5 \%$. In the other three-chamber settling tank (No. 1), COD reduction rate was $12.1 \%$. The four-chamber tanks (No. 3 and 4), just as in the case of $\mathrm{BOD}_{5}$, were significantly more efficient at removing organic contaminants than the tanks with three compartments, as they reduced $\mathrm{COD}_{\mathrm{Cr}}$ levels by $47.5 \%$ and $51.4 \%$, respectively (Fig. 3). 


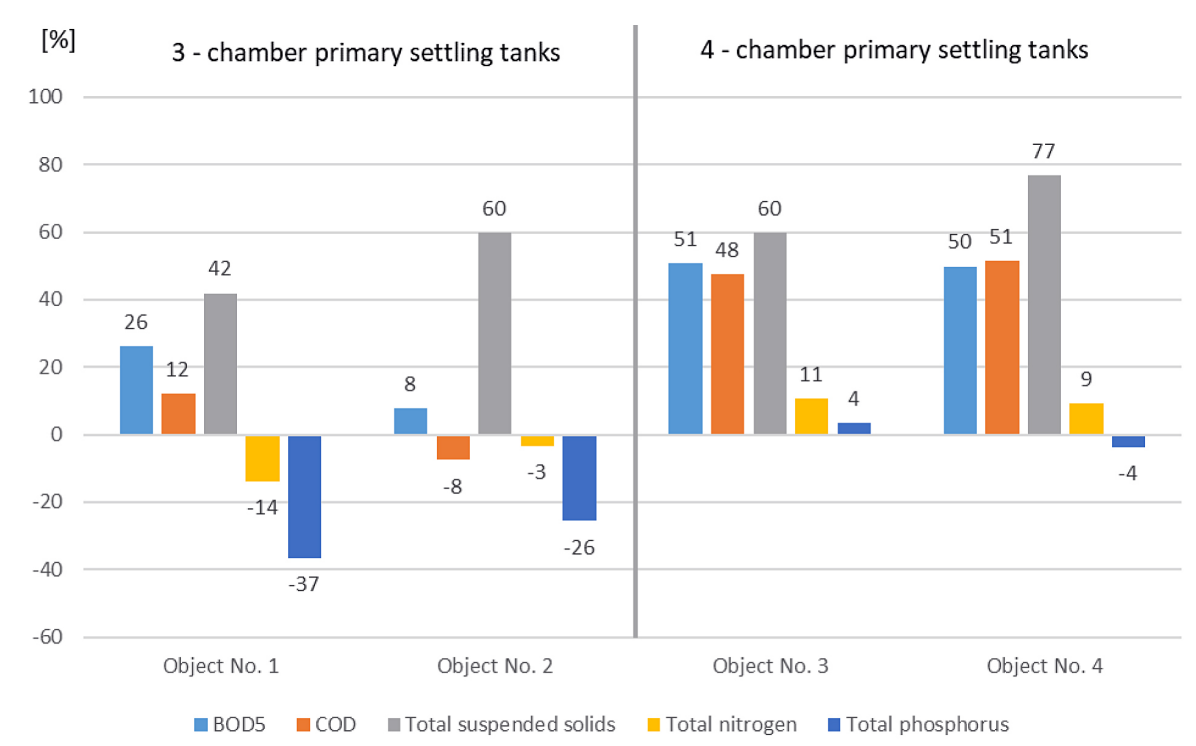

Fig. 3. Mean pollutant removal efficiencies of the primary settling tanks

Total suspended solids. The settling tanks were the most efficient at removing TSS. The four-chamber tank No. 4 removed on average $76.8 \%$ of suspended particles, showing the highest efficiency in this respect among the four tanks. Settling tanks No. 2 and 3 had a $60 \%$ mean TSS removal efficiency (Fig. 3) This result was better than the one obtained for a four-chamber settling tank $(40 \%)$ investigated by Gizińska-Górna et al. [2015]. At these removal rates, the concentrations of TSS at the outflow from the settling tanks ranged between $28.7-111.7 \mathrm{mg} \cdot \mathrm{dm}^{-3}$ (Table 3-6).

Total nitrogen and nitrogen compounds. The settling tanks investigated in the present study had very low TN and TP removal efficiencies. In fact, mechanically treated wastewater leaving the three-chamber settling tanks contained increased TN levels compared to raw wastewater. The TN removal efficiencies of the four-chamber settling tanks were also very low at $10.6 \%$ and $9.3 \%$, respectively. These results confirm the previous literature reports about the low efficiency of mechanical treatment with regard to $\mathrm{TN}$. In Gizińska-Górna et al. study [2015], a four-chamber settling tank had a $0 \%$ nitrogen removal efficiency, while a 2-chamber tank removed 19\% of this compound.

For all the examined tanks, the dominant form of nitrogen in primary settled wastewater was ammonium nitrogen, which, just as in raw sewage, represented an average of $75-85 \%$ of $\mathrm{TN}$ (Table 3-6). The concentration of $\mathrm{N}^{-\mathrm{NO}_{3}}$ in the effluent ranged from $0.62 \mathrm{mg} \cdot \mathrm{dm}^{-3}$ for tank No. 4 to $1.97 \mathrm{mg}^{\cdot} \mathrm{dm}^{-3}$ for tank No. 3. The lowest concentration of $\mathrm{N}-\mathrm{NO}_{2}\left(0.11 \mathrm{mg} \cdot \mathrm{dm}^{-3}\right)$ was recorded in settling tank No. 2.

Total phosphorus. An even less favorable trend was found for the removal of TP. As wastewater flew through the compartments of the threechamber settling tanks, the level of TP increased in it by an average of $36.5 \%$ (tank No. 1) and $25.5 \%$ (tank No. 2). The four-chamber settling tanks, had mean TP removal efficiencies of 3.51 and $-3.6 \%$ (Fig. 3) The values we recorded were clearly lower than those reported by Rothe and Lowe [2007] and Gizińska-Górna et al. [2015], despite the fact that the tanks we studied had more compartments. The increase in TP levels in mechanically treated wastewater could have been caused by the release of this component to wastewater as a result of anaerobic decomposition of bottom sediments. Because primary settling tanks fed with sewage from residential buildings accumulate larger amounts of solids at the bottom, the increase was more prominent in tanks No. 1 and 2.

Ratios between the mean values of selected pollution parameters in wastewater. The composition of wastewater flowing out of the settling tanks is of great importance from the point of view of biological treatment. Particular importance is attributed to the ratios between the following pairs of parameters: $\mathrm{COD}: \mathrm{BOD}_{5}, \mathrm{BOD}_{5}: \mathrm{TN}$, and $\mathrm{BOD}_{5}:$ TP. It has been established that biological wastewater treatment processes work properly when $\mathrm{COD}: \mathrm{BOD}_{5} \leq 2.2 ; \mathrm{BOD}_{5}: \mathrm{TN} \geq 4$; and $\mathrm{BOD}_{5}: \mathrm{TP} \geq 25$ [Heidrich et al. 2008].

Table 7 gives the ratios between the analyzed parameters, calculated on the basis of their mean 
Table 7. Ratios between the mean values of selected pollution parameters in primary settled wastewater

\begin{tabular}{|c|c|c|c|c|c|c|}
\hline $\begin{array}{c}\text { Ratio between } \\
\text { parameters }\end{array}$ & $\begin{array}{c}\text { Settling tank } \\
\text { No. 1 }\end{array}$ & $\begin{array}{c}\text { Settling tank } \\
\text { No. 2 }\end{array}$ & $\begin{array}{c}\text { Settling tank } \\
\text { No. 3 }\end{array}$ & $\begin{array}{c}\text { Settling tank } \\
\text { No. 4 }\end{array}$ & Mean value & $\begin{array}{c}\text { Recommended } \\
\text { value }\end{array}$ \\
\hline $\mathrm{COD}: \mathrm{BOD}_{5}$ & 2.88 & 3.19 & 3.39 & 2.93 & 3.1 & $\leq 2.2$ \\
\hline $\mathrm{BOD}_{5}: \mathrm{TN}$ & 1.91 & 1.30 & 0.33 & 0.73 & 1.06 & $\geq 4$ \\
\hline $\mathrm{BOD}_{5}: \mathrm{TP}$ & 10.72 & 6.51 & 4.41 & 4.94 & 6.65 & $\geq 25$ \\
\hline
\end{tabular}

levels in wastewater leaving the tanks and fed to the biological stage (constructed wetlands and activated sludge chambers). For all analyzed settling tanks, the COD: $\mathrm{BOD}_{5}$ ratio was unfavorable and ranged between 2.88-3.39. According to Młyńska et al. [2017] classification of wastewater susceptibility to biological transformation, the mechanically treated wastewater from the investigated settling tanks fell into the category of poorly biodegradable wastewater (COD:BOD ${ }_{5}=2-5$ ). The remaining ratios were also outside the favorable ranges. The low ratios of $\mathrm{BOD}_{5}$ to $\mathrm{TN}$ and $\mathrm{TP}$ in wastewater discharged from primary settling tanks may lead to poor removal of biogenic compounds in the biological stage of treatment, mainly due to the limited supply of organic compounds necessary for denitrification and dephosphatation.

\section{CONCLUSIONS}

1. The three- and four-chamber primary settling tanks we studied had mean TSS removal efficiencies of $51 \%$ and $68 \%$, respectively.

2. The four-chamber tanks reduced $\mathrm{BOD}_{5}$ and COD 4 by $50 \%$ and $49 \%$, respectively. The removal efficiency of the three-chamber settling tanks for these parameters was substantially lower at $17 \%$ and $2 \%$, respectively. These data indicate that four-chamber settling tanks show higher organic pollutant removal efficiencies than three-chamber tanks.

3. The efficiency of eliminating biogenic compounds (nitrogen and phosphorus compounds) in the four-chamber settling tanks was very low, usually below $10 \%$. The results for the threechamber settling tanks were even poorer, with primary settled wastewater containing higher concentrations of TN and TP than raw sewage, which was probably associated with the release of these elements from sewage sludge.

4. Also, the ratios between the individual pollution parameters (COD: $\mathrm{BOD}_{5}, \mathrm{BOD}_{5}: \mathrm{TN}$, $\mathrm{BOD}_{5}: \mathrm{TP}$ ) of the mechanically treated wastewater were unfavorable from the point of view of its susceptibility to biochemical degradation and removal of biogenic compounds in the biological stage.

5. Despite these negative findings, the study still shows that primary settling tanks should be used as a basic element of any domestic wastewater treatment plant, as they ensure a substantial reduction in TSS and organic matter, and limit the outflow of these pollutants to the biological stage of the sewage treatment plant.

\section{REFERENCES}

1. Błażejewski R. 2003. Kanalizacja wsi. PZITS oddział wielkopolski. Poznań, p.351.

2. Buraczyński J. 2013. Rozwój rzeźby Roztocza. Wyd. UMCS w Lublinie, p.111.

3. Chmielowski K., Bugajski P. 2008. Efektywność usuwania zanieczyszczeń w osadnikach gnilnych typu „duofilter”. Infrastruktura i Ekologia Terenów Wiejskich 5, 41-49.

4. Chmielowski K., Ślizowski R. 2009. Ocena skuteczności usuwania zanieczyszczeń w oczyszczalni ścieków w Tarnowie. Infrastruktura i Ekologia Terenów Wiejskich. No. 5/2009, Polska Akademia Nauk, Oddział w Krakowie, 137-146.

5. Dymaczewski Z.,(red.) Bartoszewski K., Bicz W., Jaroszyński T., Jeż-Walkowiak J., KomorowskaKaufman M., Kubiak Z., Kujawa-Roeleveld K., Lemański J.F., LewińskiŁ.,Łomotowski J., Mańczak M., Michałkiewicz M.,. Nalberczyński A., Niedzielski W., Oleszkiewicz J.A., Pakuła G., Sawicki M., Sozański M.M., Urbaniak A., Wasilewski M. 2011. Poradnik eksploatatora oczyszczalni ścieków. 3rd edition, PZIiTS o/Wielkopolski, Poznań, p. 1200.

6. Gizińska-Górna M., Marzec M., Jóźwiakowski K., Pytka A., Sosnowska B., Malik A., Marczuk A., Zarajczyk J., Szmigielski M, Grzywna A. 2015. Impact of chambers number of primary settling tank on the chemical and microbiological pollution removal from wastewater. Przemysł Chemiczny, 94, 11, 1958-1962.

7. Heidrich Z. 1998. Przydomowe oczyszczalnie ścieków. Poradnik. Centralny Ośrodek Informacji Budownictwa.Warszawa, p. 220.

8. Heidrich Z., Kalenik M., Podedworna J., Stańko G. 2008. Sanitacja wsi. Wyd. Seidel-Przywecki Sp. z 
o.o. Warszawa, p. 374.

9. Jawecki B., Marszałek J., Pawęska K., Sobota M., Malczewska B. 2016. Budowa i funkcjonowanie przydomowych Oczyszczalni ścieków w świetle obowiązujących przepisów - część 1. Infrastruktura i ekologia terenów wiejskich II/2, 501-516.

10. Jowett E. C. 2007. Comparing the performance of prescribed septic tank to long, narrow flooded designs, WEFTEC Technical Program 16, San Diego, p. 13.

11. Jóźwiakowski, K., 2012. Badania efektywności oczyszczania ścieków w wybranych systemach gruntowo-roślinnych. Infrastruktura i Ekologia Terenów Wiejskich 1, p. 232.

12. Jóźwiakowski K., Mucha Z., Generowicz A., Baran S., Bielińska J. Wójcik W. 2015. The use of multi-criteria analysis for selection of technology for a household WWTP compatible with sustainable development. Archives of Environmental Protection 41 (3), 76-82.

13. Jóźwiakowski K., Podbrożna D., Kopczacka K., Jaguś M., Marzec M., Listosz A., Pochwatka P., Kowalczyk-Juśko A., Malik A. 2017. The state of water and wastewater management in the municipalities of the Roztoczanski National Park. Journal of Ecological Engineering, 19(2), 255-262.

14. Kuczewski K. 1993. Efekty oczyszczania ścieków bytowo-gospodarczych w trzykomorowym osadniku gnilnym. Zeszyty Probl. PZiTS „Technika Sanitarna Wsi” 672/1993, 97-103.

15. Maciołek P., Janowska B., Szymański K. 2016. Usuwanie azotu ze ścieków komunalnych z wykorzystaniem zewnętrznego źródła węgla organicznego. Rocznik Ochrona Środowiska, Tom 18, 885-896.

16. Makowska M., Pawlak M., Mazurkiewicz J. 2018. Oczyszczanie wstępne w przydomowych oczyszczalniach ścieków. Gaz, woda i technika sanitarna 1 (6), 16-20.

17. Masłoń A., Tomaszek J. 2013. Ocena efektywności oczyszczalni ścieków w Lubaczowie. Journal of civil engineering, environment and architecture JCEEA, Vol. XXX, Issue. 60 (3/13), 209-222.

18. Miernik W., Młyński D. 2014. Analiza efektywności pracy oczyszczalni ścieków w Krzeszowicach po modernizacji. EPISTEME 22/2014, vol. II pp. 303-310 ISSN, 1895-2241.

19. Młyńska A., Chmielowski K., Młyński D. 2017. The analysis of the changes in the sewage quality during treatment processes on the wastewater treatment plant in Przemyśl. Inżynieria Ekologiczna, Vol. 18 (5), 18-26.

20. Mucha J. 1994. Metody geostatystyczne w dokumentowaniu złóż. Skrypt, Katedra Geologii Kopalnianej. AGH Kraków, p. 155.
21. Osmulska-Mróz B. 1995. Lokalne systemy unieszkodliwiania ścieków. Poradnik. Instytut Ochrony Środowiska, Warszawa, p. 219.

22. Paluch J., Paruch A., Pulikowski K. 2006. Wstępne wyniki badań oczyszczalni zagrodowej typu ORP. Woda-Środowisko-Obszary Wiejskie, 6, 1, 297-305.

23. Pawęska K., Pulikowski K., Strzelczyk M., Rajmund A. 2011. Osadnik gnilny - podstawowy element przydomowej oczyszczalni ścieków. Infrastruktura i Ekologia Terenów Wiejskich. No. 10/2011, 43-53.

24. Philippi L. S., Costa R. H. R. and Sezerino P. H. 1999. Domestic effluent treatment through integrated system of septic tank and root zone. Wat. Sci. Tech., 40 (3), 125-131.

25. PN-74/C-04620/00. - ,Woda i ścieki - Pobieranie próbek. Postanowienie ogólne i zakres normy".

26. Polish Norm PN-EN 12566-3:2016-10. 2016. Small wastewater treatment plants for a population calculation (OLM) up to 50 - Part 3: Container and/ or home sewage treatment plants on site.

27. Razmi, B. Firoozabadi, B. Ahmadi. 2009. Experimental and Numerical Approach to Enlargement of Performance of Primary Settling Tanks, Journal of Applied Fluid Mechanics, Vol. 2, No. 1, 1-12.

28. Rothe N. K., Lowe K. S., 2007. Wastewater composition and variability as obtained from literature source, WEFTEC Technical Program 16, San Diego, pp. 13.

29. Sadecka Z., Płuciennik-Koropczuk E. 2011. Frakcje ChZT ścieków w mechaniczno-biologicznej oczyszczalni. Rocznik Ochrona Środowiska. Vol. 13, ISSN 1506-218X 1157-1172.

30. Seabloom R. W., Bounds T. R., Loudon T. 2004. Septic Tank, University Curriculum Development for Decentralized Wastewater Management, EPA, pp. 45 .

31. Shahrokhi, M., Rostami, F., Md Said, M., and Syafalni. 2013. Numerical modeling of baffle location effects on the flow pattern of primary sedimentation tanks. Applied Mathematical Modelling, Volume 37, Issue 6, 4486-4496.

32. Świeca A., Krukowska R., Tucki A., Grabowski T. 2016. Wybrane aspekty rozwoju ruchu turystycznego w Roztoczańskim Parku Narodowym. Ekonomiczne Problemy Turystyki 3/2016 (35), 123-134.

33. Tamayol A., Firoozabadi, B., Ashjari M. 2010. Hydrodynamics of Secondary Settling Tanks and Increasing Their Performance Using Baffles. Journal of Environmental Engineering 136 (1), 32-39.

34. Water Law 2017. (Prawo wodne) Ustawa z dnia 20 lipca 2017 r., Dz.U. 2017 poz. 1566.

35. Wiejak A. 2013. Redukcja fosforu ogólnego w ściekach z małych przydomowych oczyszczalni. Prace Instytutu Techniki Budowlanej 1, p. 165. 